\title{
Could the invasive scleractinians Tubastraea coccinea and T. tagusensis replace the dominant zoantharian Palythoa caribaeorum in the Brazilian subtidal?
}
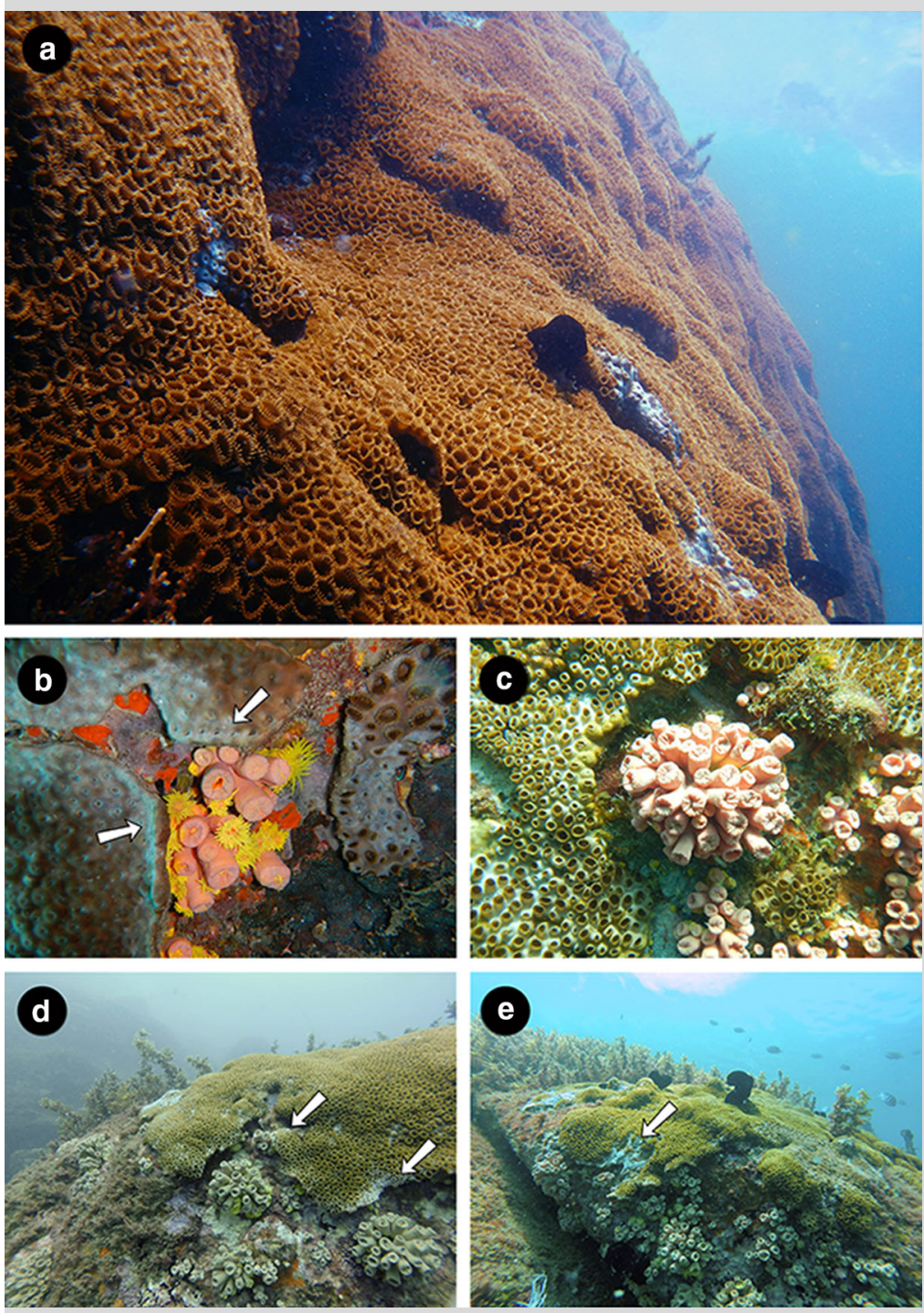

Fig. 1 a Natural dominance of Palythoa caribaeorum on shallow-water rocky shores of southeastern Brazil. b-e Series of images showing Tubastraea tagusensis outcompeting P. caribaeorum. Arrows indicate damaged/necrosed tissue of $P$. caribaeorum due to direct contact with $T$. tagusensis. $\mathbf{c}-\mathbf{e}$ Note the halo in the zoantharian formed by the tissue expansion of T. tagusensis
Commonly known as sun corals, Tubastraea coccinea and T. tagusensis are invasive scleractinians that are changing the marine biodiversity of Brazilian coastal ecosystems. Since their first report in Brazilian waters (an offshore oil platform in the Campos Basin; Castro and Pires 2001), both species have spread over more than $3000 \mathrm{~km}$ in the SW Atlantic, threatening endemic species such as Mussismilia hispida (Creed et al. 2017). At Ilha dos Búzios, São Paulo, a locality where the invasion has covered the vertical portion of the infralittoral, we observed that sun corals are outcompeting Palythoa caribaeorum. The latter is one of the most dominant species in shallow waters along the Brazilian coast (Fig. 1a). Palythoa caribaeorum is considered an aggressive competitor due to the production of palytoxin (Gleibs et al. 1995), but when in direct contact with sun corals, $P$. caribaeorum colonies receded or necrosed (Fig. 1b-e). Thus, since $P$. caribaeorum is a community structuring species on Brazilian rocky shores, its replacement with the invasive sun corals may change biodiversity and community dynamics in shallow waters. Monitoring and management is urgently needed to control invasive Tubastrea spp. and the potential biodiversity loss due to their invasion.

Acknowledgements The authors thank the São Paulo University Marine Biology Centre (CEBIMar) for their support. B.L.P. Luz gratefully acknowledges the Coastal and Ocean Systems Graduate Program and Higher Education Personnel Improvement Coordination for the Ph.D. scholarship.

\section{References}

Castro CB, Pires DO (2001) Brazilian coral reefs: what we already know and what is still missing. Bull Mar Sci 69:357-371

Creed JC, Fenner D, Sammarco P, Cairns SD, Capel KCC, Junqueira AO, Cruz I, Miranda RJ, Carlos-Junior L, Mantelatto MC, Oigman-Pszczol S (2017) The invasion of the azooxanthellate coral Tubastraea (Scleractinia: Dendrophylliidae) throughout the world: history, pathways and vectors. Biol Invasions 19:283-305

Gleibs S, Mebs D, Werding B (1995) Studies on the origin and distribution of palytoxin in a Caribbean coral reef. Toxicon 33:1531-1537

B. L. P. Luz (D) (凹) · M. V. Kitahara

Programa de Pós-graduação em Sistemas Costeiros e Oceânicos, Centro de Estudos do Mar, Universidade Federal do Paraná, Pontal do Paraná, Brazil e-mail: bruna.luz@ufpr.br

B. L. P. Luz · M. V. Kitahara

Centro de Biologia Marinha, Universidade de São Paulo, São Sebastião, Brazil

M. V. Kitahara

Departamento de Ciências do Mar, Universidade Federal de São Paulo, Santos, Brazil

Received: 4 January 2017/Accepted: 29 March 2017/Published online: 19 April 2017

Coral Reefs (2017) 36:875

(C) Springer-Verlag Berlin Heidelberg 2017

DOI $10.1007 / \mathrm{s} 00338-017-1578-5$ 